\title{
Lactobacillus nantensis sp. nov., isolated from French wheat sourdough
}

Correspondence
Maher Korakli
maher.korakli@wzw.tum.de

Sourdough fermentation is a process used to obtain bread dough from wheat or rye flour by the combined metabolic activity of lactic acid bacteria (LAB) and yeasts (Hammes \& Gänzle, 1998). Because of the superior sensory quality and the prolonged shelf life of the resulting baked goods, sourdough processes have retained their importance in modern baking technology (Stolz et al., 1996; Ottogalli et al., 1996). Yeasts contribute predominantly to dough leavening, whereas LAB are responsible for acidification, aroma formation and sensorial as well as nutritional improvement of the fermented product (Vogel et al., 1999; Böcker et al., 1990). Knowledge regarding LAB diversity is thus essential in sourdough investigations.

Published online ahead of print on 4 November 2005 as DOI 10.1099/ ijs.0.63619-0.

Abbreviations: AFLP, amplified fragment length polymorphism; LAB, lactic acid bacteria; RAPD, randomly amplified polymorphic DNA; RFLP, restriction fragment length polymorphism.

The GenBank/EMBL/DDBJ accession number for the $16 \mathrm{~S}$ rRNA gene sequence of strain $\mathrm{LP}^{\mathrm{T}}{ }^{\top}$ is $\mathrm{AY} 690834$.

RAPD and AFLP patterns of Lactobacillus nantensis $\mathrm{LP}^{\top}{ }^{\top}$ and selected reference sourdough lactobacilli are shown in supplementary figures available in IJSEM Online.
Recent studies of the LAB microbiota of sourdoughs have employed traditional cultivation methods in combination with phenotypic (physiological and biochemical) and/or genotypic [e.g. randomly amplified polymorphic DNA (RAPD) and restriction fragment length polymorphism (RFLP) analyses] identification methods (Galli et al., 1988; Mäntynen et al., 1999; Rocha \& Malcata, 1999; Corsetti et al., 2001; Bervas, 1991; Onno \& Roussel, 1994; Gabriel et al., 1999; Valcheva et al., 2005). The majority of LAB isolated from sourdoughs belong to the genus Lactobacillus, and more than 50 Lactobacillus species have been isolated in relevant cell counts from sourdough. Sourdoughs prepared by traditional procedures, type I sourdough, are characterized by the association between homo- and heterofermentative lactobacilli (Vogel et al., 1999). Lactobacillus sanfranciscensis is most frequently isolated and was thus designated as a key organism in type I sourdough. The homofermentative species Lactobacillus plantarum and Lactobacillus alimentarius are also usually isolated (Vogel et al., 1999; Corsetti et al., 2001; De Vuyst et al., 2002; Valcheva et al., 2005). Industrial fermentations are carried out at elevated temperature and over prolonged periods. In these fermentations, producing type II sourdough, Lactobacillus reuteri, Lactobacillus fermentum, Lactobacillus acidophilus and Lactobacillus amylovorus 
are often isolated (Vogel et al., 1999; Hammes \& Gänzle, 1998; Meroth et al., 2003). Recent aims to characterize sourdough microflora by using a polyphasic taxonomic approach have resulted in the description of several novel Lactobacillus species, namely Lactobacillus frumenti (Müller et al., 2000), L. mindensis (Ehrmann et al., 2003), L. spicheri (Meroth et al., 2004), L. hammesii (Valcheva et al., 2005), L. zymae and L. acidifarinae (Vancanneyt et al., 2005) and L. rossii (Corsetti et al., 2005).

In the present study, the $\mathrm{LAB}$ of a traditional French wheat sourdough were investigated. A preliminary screening based on observed phenotypic characteristics led to the isolation of 30 bacterial strains. Additional information regarding the taxonomic status at species and strain level was obtained by amplified-fragment length polymorphism (AFLP) and RAPD analyses. These methods allowed the identification to species level of almost all LAB involved in this sourdough fermentation. However, a consistent group of 14 strains could be clearly discriminated from recognized Lactobacillus species. On the basis of the phenotypic and genotypic results obtained from a representative strain of this group, $\mathrm{LP} 33^{\mathrm{T}}$, a novel Lactobacillus species is described.

The traditional French wheat sourdough used for this study was a firm sourdough originating from initially spontaneous fermentation of flour and water (dough yield $160 \mathrm{~kg}$ dough per $100 \mathrm{~kg}$ flour) at $18-20^{\circ} \mathrm{C}$. It was maintained by back slopping (repeated cycles of re-inoculation of flour, water and $30 \%$ inoculum from the previous fermentation) under the same conditions. Sourdough samples used for bread preparation were taken aseptically, stored at $4{ }^{\circ} \mathrm{C}$ and analysed immediately. The LAB population was enumerated as described by Valcheva et al. (2005). After $48-72 \mathrm{~h}$ incubation at $30^{\circ} \mathrm{C}$ under anaerobic conditions, the number of colonies with similar morphology and the total number of LAB (as c.f.u. $\mathrm{g}^{-1}$ ) were estimated. The distribution of various colony forms was recorded and the relative distribution of the various isolates was determined. Thirty colonies representing these different morphological forms were picked and purified on the same medium by successive subculturing at $30^{\circ} \mathrm{C}$. Pure isolates were stored in $20 \%$ $\left(\right.$ w/v) glycerol stock cultures at $-80^{\circ} \mathrm{C}$.

Lactobacillus reference strains used were L. alimentarius LMG $9187^{\mathrm{T}}\left(=\right.$ DSM $\left.20249^{\mathrm{T}}\right)$, L. alimentarius LMG 9188t2, Lactobacillus brevis DSM $20054^{\mathrm{T}}$, L. farciminis LMG $9200^{\mathrm{T}}$ $\left(=\right.$ DSM $\left.20184^{\mathrm{T}}\right)$, L. hammesii DSM $16381^{\mathrm{T}}$, Lactobacillus kimchii DSM $13961^{\mathrm{T}}$, L. kimchii LMG $19822^{\mathrm{T}}$, L. mindensis DSM $14500^{\mathrm{T}}\left(=\mathrm{LMG} 21932^{\mathrm{T}}\right)$, L. paralimentarius DSM $13238^{\mathrm{T}}$ ( = LMG $\left.19152^{\mathrm{T}}\right)$, L. sanfranciscensis DSM $20451^{\mathrm{T}}$, L. spicheri DSM $15429^{\mathrm{T}}$ and L. versmoldensis LMG $21929^{\mathrm{T}}$ $\left(=\mathrm{DSM} 14857^{\mathrm{T}}\right)$. They were grown anaerobically on mMRS4 medium at the appropriate temperature (Stolz et al., 1996). All tests were performed at $30^{\circ} \mathrm{C}$ unless otherwise stated. Colony morphology, Gram staining and cellular morphology were determined on cells grown anaerobically on mMRS4 incubated for 2 days. All tests for biochemical characterizations were carried out at least in duplicate, and as described by Valcheva et al. (2005).

DNA was isolated according to the method of Marmur (1961) with the modification described by Ehrmann et al. (2003). The isolated DNA was used for 16S rRNA gene sequence amplification and for RAPD analysis. The complete $16 \mathrm{~S}$ rRNA gene was amplified using primers fD1 and rD1 as described by Weisburg et al. (1991). A clone library of the 16S rRNA gene amplified with primers fD1 and $\mathrm{rD} 1$ of strain LP33 ${ }^{\mathrm{T}}$ was constructed in Escherichia coli JM109 using the pDrive cloning kit (Qiagen) and the insert of positive clones was sequenced. Primers T7-pro and SP6 flanking the multiple cloning site of pDrive DNA were used for sequencing. Internal primers 609R, 612R, 607R, 606R and 607V were additionally used for sequence verification (Ehrmann et al., 2003). The complete $16 \mathrm{~S}$ rRNA gene sequence of $\mathrm{LP} 33^{\mathrm{T}}$ was included in the phylogenetic analysis. A phylogenetic tree was constructed according to the neighbour-joining method using BioNumerics software (Applied Maths). RAPD-PCR was carried out as described by Ehrmann et al. (2003). The AFLP patterns of the sourdough isolates were compared with those of the reference strains. AFLP analysis was performed according to a modification of the procedure described by Gevers et al. (2001). DNA-DNA relatedness analysis was carried out as described by De Ley et al. (1970), with the modifications described by Escara \& Hutton (1980) and Huß et al. (1983), and was performed using the fluorometric method as described by Ezaki et al. (1989). AFLP and DNA-DNA hybridization experiments were carried out in duplicate by $\mathrm{BCCM}^{\mathrm{TM}} / \mathrm{LMG}$. Cell wall composition and DNA G $+C$ content were determined by the DSMZ according to the methods of Schleifer \& Kandler (1972) and Mesbah \& Whitman (1989), respectively.

The LAB microflora of the sourdough described above was determined qualitatively and quantitatively. This sourdough had a $\mathrm{pH}$ of 3.65 and total titratable acidity (TTA) of $26.6 \mathrm{ml}$ $(10 \mathrm{~g})^{-1}$. The LAB population was $1 \cdot 7 \times 10^{9}$ c.f.u. $\mathrm{g}^{-1}$. Thirty morphologically different colonies were isolated and were further characterized morphologically and physiologically. On this basis, the bacterial population was divided into three groups of Gram-positive, catalase-negative rods: (i) heterofermentative with growth at $15^{\circ} \mathrm{C}$ but not at $45^{\circ} \mathrm{C}$, (ii) homofermentative with growth at 15 and $45^{\circ} \mathrm{C}$ and (iii) homofermentative with growth at $15{ }^{\circ} \mathrm{C}$ but not at $45^{\circ} \mathrm{C}$. Additionally, these isolates were clustered based on RFLP analysis of 16S-23S rRNA intergenic spacer regions (data not shown). According to RFLP and phenotypic analysis, the Lactobacillus microflora of the sourdough was characterized as a consortium of $37 \%$ L. hammesii ( 11 isolates), $17 \%$ L. plantarum (five isolates) and $46 \%$ unknown (14 isolates). One representative strain of each cluster was subsequently identified based on 16S rRNA gene sequencing, RAPD and AFLP analyses. The results confirmed the initially presumed phylogenetic status of the first two groups of isolates as representing L. hammesii and L. plantarum. RAPD and carbohydrate fermentation patterns of five selected 
strains of the third group were identical, indicating that at least five of the 14 isolates represent the same species. Isolate LP $33^{\mathrm{T}}$, representative of the third group, was not assignable to any recognized species and was therefore included in a polyphasic approach using RAPD and AFLP genotyping methods. Strategies combining different typing methods, e.g. SDS-PAGE of cellular proteins, RAPD-PCR and AFLP, have increasingly been used to identify closely related species and strains (Valcheva et al., 2005; Gancheva et al., 1999). RAPD-PCR of isolate LP33 ${ }^{\mathrm{T}}$ and 11 reference Lactobacillus species usually found in sourdough was performed. The dendrogram thus constructed clearly indicated the separate taxonomic position of strain LP33 ${ }^{\mathrm{T}}$. Similarly, strain LP33 ${ }^{\mathrm{T}}$ was included in AFLP analysis. The AFLP dendrogram constructed placed strain $\mathrm{LP} 33^{\mathrm{T}}$ in a cluster together with L. kimchii LMG $19822^{\mathrm{T}}$, L. paralimentarius $\mathrm{LMG} 19152^{\mathrm{T}}$ and seven isolates of $L$. paralimentarius. The RAPD and AFLP patterns are available as Supplementary Figs S1 and S2 in IJSEM Online.

The complete sequence (1561 bp) of the 16S rRNA gene sequence of LP $33^{\mathrm{T}}$ was determined. In a neighbour-joining dendrogram based on the sequence of LP $33^{\mathrm{T}}$ from this study and sequences from the GenBank database, the phylogenetic position of $\mathrm{LP} 33^{\mathrm{T}}$ was determined. $\mathrm{LP} 33^{\mathrm{T}}$ was placed within the $L$. plantarum group and was phylogenetically most closely related to L. farciminis, L. alimentarius, L. paralimentarius, L. mindensis and L. versmoldensis (Fig. 1). 16S rRNA gene sequence similarity between LP $33^{\mathrm{T}}$ and L. farciminis DSM $20184^{\mathrm{T}}$, L. mindensis DSM $14500^{\mathrm{T}}$ and L. paralimentarius DSM $13238^{\mathrm{T}}$ was $97 \cdot 5,97 \cdot 4$ and $96 \cdot 7 \%$, respectively.

DNA-DNA hybridization analyses were performed, including the three most closely related species based on $16 \mathrm{~S}$ rRNA gene sequence analysis. DNA-DNA relatedness values between LP33 ${ }^{\mathrm{T}}$ and L. farciminis DSM $20184^{\mathrm{T}}$, L. mindensis DSM $14500^{\mathrm{T}}$ and L. paralimentarius DSM $13238^{\mathrm{T}}$ were $27 \pm 3,27 \pm 3$ and $22 \pm 2 \%$, respectively (average \pm range of two values). These values are well below the threshold of $70 \%$ suggested for species delineation (Stackebrandt \& Goebel, 1994), indicating that strain $\mathrm{LP}^{\mathrm{T}}{ }^{\mathrm{T}}$ represents a separate genomic species. The DNA G $+\mathrm{C}$ content of LP $33^{\mathrm{T}}$ was $38.6 \mathrm{~mol} \%$, which is within the range $32-55 \mathrm{~mol} \%$ reported for Lactobacillus species (Kandler \& Weiss, 1986). Analysis of the cell wall composition of strain LP33 ${ }^{\mathrm{T}}$ revealed the presence of lysine and aspartic acid, indicating A4 $\alpha$ L-Lys-D-Asp peptidoglycan type.

Cells of strain $\mathrm{LP}^{\mathrm{T}}{ }^{\mathrm{T}}$ were Gram-positive, non-motile, lacked endospores and had irregular internal granulation as revealed by methylene blue staining. After incubation on MRS agar for 3 days, colonies were white, circular to slightly irregular, convex, with a smooth to rough surface and diameter of $0 \cdot 8-1 \cdot 5 \mathrm{~mm}$. Strain LP $33^{\mathrm{T}}$ exhibited no oxidase or catalase activities. In mMRS4 at pH 6.5 and $30^{\circ} \mathrm{C}$, the specific growth rate of strain LP33 $3^{\mathrm{T}}$ was $0 \cdot 48 \pm 0 \cdot 01 \mathrm{~h}^{-1}$. The optimal temperature for growth was in the range $30-35{ }^{\circ} \mathrm{C}$; the specific growth rate was only 46 and $44 \%$ $\left(100 \%\right.$ at $\left.30^{\circ} \mathrm{C}\right)$ at 20 and $40^{\circ} \mathrm{C}$, respectively. $\mathrm{LP} 33^{\mathrm{T}}$ grew well at initial $\mathrm{pH}$ values of $4 \cdot 4-7 \cdot 7$; the specific growth rate was only 4 and $22 \%(100 \%$ at pH $6 \cdot 5)$ at $\mathrm{pH} 3 \cdot 0$ and $9 \cdot 2$, respectively. $\mathrm{LP}^{\mathrm{T}}{ }^{\mathrm{T}}$ grew well at an $\mathrm{NaCl}$ content of up to $2 \%$; the specific growth rate was 73 and $56 \%(100 \%$ without $\mathrm{NaCl}$ ) at 3 and $5 \% \mathrm{NaCl}$, respectively. The carbohydrate fermentation patterns of strain $\mathrm{LP} 33^{\mathrm{T}}$ are given in Table 1.

On the basis of $16 \mathrm{~S}$ rRNA gene sequence analysis, DNADNA reassociation values, RAPD and AFLP fingerprinting analyses as well as phenotypic characteristics, we propose that strain LP33 ${ }^{\mathrm{T}}$ be classified as the type strain of a novel Lactobacillus species, for which the name Lactobacillus nantensis is proposed.

\section{Description of Lactobacillus nantensis sp. nov.}

Lactobacillus nantensis (nan.ten'sis. M.L. masc. adj. nantensis pertaining to Nantes, from where the first strain of this species was isolated).

Cells are Gram-positive, $2-5 \mu \mathrm{m}$ long and $1.0 \mu \mathrm{m}$ wide, non-motile, non-spore-forming rods with irregular internal

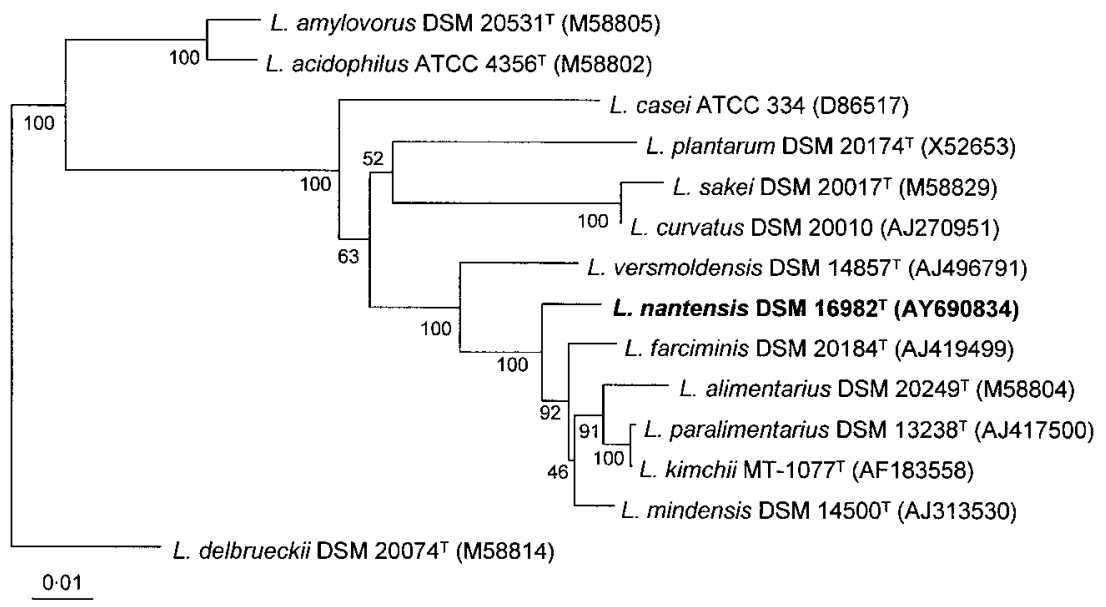

Fig. 1. Phylogenetic tree derived from 16S rRNA gene sequence analysis, giving the position of Lactobacillus nantensis sp. nov. DSM $16982^{\top} \quad\left(=\right.$ LP33 $\left.^{\top}\right)$ among selected lactobacilli. The tree was generated by the neighbour-joining method based on a comparison of approximately $1450 \mathrm{nt}$. Bootstrap values based on 1000 replications are given at branching points. Bar, 1\% sequence divergence. 
Table 1. Differential phenotypic characteristics of Lactobacillus nantensis sp. nov. $\mathrm{LP}^{\mathrm{T}}{ }^{\top}$ and closely related Lactobacillus species

Strains: 1, L. nantensis $\mathrm{LP}^{\mathrm{T}}{ }^{\mathrm{T}}$; 2, L. farciminis DSM $20184^{\mathrm{T}}$ (data from Reuter, 1983); 3, L. alimentarius DSM $20249^{\mathrm{T}}$ (Reuter, 1983); 4, L. paralimentarius JCM $10415^{\mathrm{T}}$ (Cai et al., 1999); 5, L. kimchii JCM $10707^{\mathrm{T}}$ (Yoon et al., 2000); 6, L. mindensis DSM $14500^{\mathrm{T}}$ (Ehrmann et al., 2003). All strains are of L-Lys-D-Asp peptidoglycan type and DL-lactate configuration. +, Positive; -, negative; $\mathrm{W}$, weakly positive; ND, no data.

\begin{tabular}{|lcccccc|}
\hline Characteristic & $\mathbf{1}$ & $\mathbf{2}$ & $\mathbf{3}$ & $\mathbf{4}$ & $\mathbf{5}$ & $\mathbf{6}$ \\
\hline DNA G+C content & $38 \cdot 6$ & $34-36$ & $36-37$ & $37 \cdot 2-38$ & 35 & $37 \cdot 5$ \\
$($ mol\% $)$ & & & & & & \\
$\mathrm{NH}_{3}$ from arginine & - & - & - & $\mathrm{ND}$ & - & - \\
Growth at $15 / 45^{\circ} \mathrm{C}$ & + / & + / & + / & $\mathrm{ND} /-$ & + / & + /- \\
Carbohydrate fermentations: & & & & & \\
L-Arabinose & - & - & - & - & + & - \\
D-Xylose & - & - & - & - & + & - \\
Ribose & $\mathrm{W}$ & - & + & + & - & - \\
Galactose & + & + & + & - & + & - \\
Mannitol & + & - & - & - & - & - \\
Methyl $\alpha$-D- & + & - & - & - & - & - \\
mannoside & & & & & & \\
Sorbitol & + & - & - & - & - & - \\
$N$-Acetylglucosamine & + & - & + & + & - & + \\
Amygdalin & + & - & + & + & - & $\mathrm{W}$ \\
Arbutin & + & - & + & + & - & - \\
Aesculin & + & + & + & + & + & - \\
Maltose & + & $\mathrm{W}$ & + & $\mathrm{W}$ & + & + \\
Lactose & + & + & - & - & - & - \\
Sucrose & + & + & + & + & + & - \\
Melibiose & + & - & - & - & - & - \\
Trehalose & + & $\mathrm{W}$ & + & + & + & - \\
Raffinose & + & $\mathrm{W}$ & - & - & - & - \\
Melezitose & - & - & - & - & + & - \\
$\beta$-Gentiobiose & + & - & - & + & + & - \\
D-Tagatose & + & - & - & - & - & - \\
& & & & & & \\
\hline
\end{tabular}

granulation. They occur singly, in pairs or in chains. Colonies are small $(1.5 \mathrm{~mm})$, circular to slightly irregular, convex, with a smooth to rough surface and white when grown on MRS agar. Cells grow well in liquid and solid MRS under anaerobic conditions. The optimum growth temperature is $30{ }^{\circ} \mathrm{C}$ and the optimal initial $\mathrm{pH}$ is $4 \cdot 4-7 \cdot 7$. Strain $\mathrm{LP}_{3}{ }^{\mathrm{T}}$ is able to grow at up to $8 \% \mathrm{NaCl}$. Cells are catalaseand oxidase-negative. Glucose is metabolized homofermentatively and lactate is the sole final product. Strain LP33 ${ }^{\mathrm{T}}$ produces $\mathrm{L}(+)$ - and $\mathrm{D}(-)$-lactic acid. Acid is produced from glucose, fructose, mannose, galactose, cellobiose, maltose, lactose, melibiose, sucrose, trehalose, raffinose, $\beta$-gentiobiose, tagatose, mannitol, sorbitol, methyl $\alpha$-Dmannoside, $N$-acetylglucosamine, amygdalin, arbutin, aesculin and salicin. Ribose is weakly fermented. Ammonia is not produced from arginine. Citrate is utilized weakly in the absence of glucose.
The type strain is $\mathrm{LP}^{\mathrm{T}} 3^{\mathrm{T}}\left(=\mathrm{DSM} 16982^{\mathrm{T}}=\mathrm{CIP} 108546^{\mathrm{T}}=\right.$ TMW $1.1265^{\mathrm{T}}$ ).

\section{Acknowledgements}

We thank G. Ouisse's bakery for kindly providing the sourdough sample. This work was supported by the Région Pays de la Loire and by the French Ministries (Ministère des Affaires Etrangères and Ministère de l'Agriculture et de la Pêche). Hans G. Trüper and Jean Euzéby are acknowledged for consultation regarding nomenclature and Stefanie Zehetmair for the biochemical characterization.

\section{References}

Bervas, E. (1991). Mise au point de levains bactériens pour la panification. Thèse de Doctorat, Université Blaise Pascal, ClermontFerrand, France (in French).

Böcker, G., Vogel, R. F. \& Hammes, W. P. (1990). Lactobacillus sanfrancisco als stabiles Element in einem Reinzucht-SauerteigPräparat. Getreide Mehl Brot 44, 269-274 (in German).

Cai, Y., Okada, H., Mori, H., Benno, Y. \& Nakase, T. (1999). Lactobacillus paralimentarius sp. nov., isolated from sourdough. Int J Syst Bacteriol 49, 1451-1455.

Corsetti, A., Lavermicocca, P., Morea, M., Baruzzi, F., Tosti, N. \& Gobbetti, M. (2001). Phenotypic and molecular identification and clustering of lactic acid bacteria and yeasts from wheat (species Triticum durum and Triticum aestivum) sourdoughs of Southern Italy. Int J Food Microbiol 64, 95-104.

Corsetti, A., Settanni, L., van Sinderen, D., Felis, G. E., Dellaglio, F. \& Gobbetti, M. (2005). Lactobacillus rossii sp. nov. isolated from wheat sourdough. Int J Syst Evol Microbiol 55, 35-40.

De Ley, J., Cattoir, H. \& Reynaerts, A. (1970). The quantitative measurement of DNA hybridization from renaturation rates. Eur J Biochem 12, 133-142.

De Vuyst, L., Schrijvers, V., Paramithiotis, S., Hoste, B., Vancanneyt, M., Swings, J., Kalantzopoulos, G., Tsakalidou, E. \& Messens, W. (2002). The biodiversity of lactic acid bacteria in Greek traditional wheat sourdoughs is reflected in both composition and metabolite formation. Appl Environ Microbiol 68, 6059-6069.

Ehrmann, M. A., Muller, M. R. \& Vogel, R. F. (2003). Molecular analysis of sourdough reveals Lactobacillus mindensis sp. nov. Int J Syst Evol Microbiol 53, 7-13.

Escara, J. F. \& Hutton, J. R. (1980). Thermal stability and renaturation of DNA in dimethyl sulfoxide solutions: acceleration of the renaturation rate. Biopolymers 19, 1315-1327.

Ezaki, T., Hashimoto, Y. \& Yabuuchi, E. (1989). Fluorometric deoxyribonucleic acid-deoxyribonucleic acid hybridization in microdilution wells as an alternative to membrane filter hybridization in which radioisotopes are used to determine genetic relatedness among bacterial strains. Int J Syst Bacteriol 39, 224-229.

Gabriel, V., Lefebvre, D., Vayssier, Y. \& Faucher, C. (1999). Characterisation of microflora from natural sourdoughs. Microbiol Aliment Nutr 17, 171-179.

Galli, A., Franzetti, L. \& Fortina, M. G. (1988). Isolation and identification of sourdough microflora. Microbiol Aliment Nutr 6, 345-351.

Gancheva, A., Pot, B., Vanhonacker, K., Hoste, B. \& Kersters, K. (1999). A polyphasic approach towards the identification of strains belonging to Lactobacillus acidophilus and related species. Syst Appl Microbiol 22, 573-585. 
Gevers, D., Huys, G. \& Swings, J. (2001). Applicability of rep-PCR fingerprinting for identification of Lactobacillus species. FEMS Microbiol Lett 205, 31-36.

Hammes, W. P. \& Gänzle, M. G. (1998). Sourdough breads and related products. In Microbiology of Fermented Foods, vol. 1, pp. 199-216. Edited by B. J. B. Woods. London: Chapman \& Hall.

Huß, V. A. R., Festl, H. \& Schleifer, K. H. (1983). Studies on the spectrophotometric determination of DNA hybridization from renaturation rates. Syst Appl Microbiol 4, 184-192.

Kandler, O. \& Weiss, N. (1986). The genus Lactobacillus. In Bergey's Manual of Systematic Bacteriology, vol. 2, pp. 1208-1234. Edited by P. H. A. Sneath, N. S. Mair, M. E. Sharpe \& J. G. Holt. Baltimore: Williams \& Wilkins.

Mäntynen, V. H., Korhola, M., Gudmundsson, H., Turakainen, H., Alfredsson, G. A., Salovaara, H. \& Lindström, K. (1999). A polyphasic study on the taxonomic position of industrial sourdough yeasts. Syst Appl Microbiol 22, 87-96.

Marmur, J. (1961). A procedure for the isolation of deoxyribonucleic acid for micro-organisms. J Mol Biol 3, 208-218.

Meroth, C. B., Walter, J., Hertel, C., Brandt, M. J. \& Hammes, W. P. (2003). Monitoring the bacterial population dynamics in sourdough fermentation processes by using PCR-denaturing gradient gel electrophoresis. Appl Environ Microbiol 69, 475-482.

Meroth, C. B., Hammes, W. P. \& Hertel, C. (2004). Characterisation of the microbiota of rice sourdoughs and description of Lactobacillus spicheri sp. nov. Syst Appl Microbiol 27, 151-159.

Mesbah, M. \& Whitman, W. B. (1989). Measurement of deoxyguanosine/thymidine ratios in complex mixtures by high-performance liquid chromatography for determination of the mole percentage guanine + cytosine of DNA. J Chromatogr 479, 297-306.

Müller, M. R., Ehrmann, M. A. \& Vogel, R. F. (2000). Lactobacillus frumenti sp. nov., a new lactic acid bacterium isolated from rye-bran fermentations with a long fermentation period. Int $J$ Syst Evol Microbiol 50, 2127-2133.

Onno, B. \& Roussel, P. (1994). Technologie et microbiologie de la panification au levain. In Bactéries lactiques, vol. II, pp. 293-321.
Edited by H. de Roissart \& F. M. Luquet. Uriage, France: Lorica (in French).

Ottogalli, G., Galli, A. \& Foschino, R. (1996). Italian bakery products obtained with sourdough: characterization of the typical microflora. Adv Food Sci 18, 131-144.

Reuter, G. (1983). Lactobacillus alimentarius sp. nov., nom. rev. and Lactobacillus farciminis sp. nov., nom. rev. Syst Appl Microbiol 4, 277-279.

Rocha, J. M. \& Malcata, F. X. (1999). On the microbiological profile of traditional Portuguese sourdough. J Food Prot 62, 1416-1429.

Schleifer, K. H. \& Kandler, O. (1972). Peptidoglycan types of bacterial cell walls and their taxonomic implications. Bacteriol Rev 36, 407-477.

Stackebrandt, E. G. \& Goebel, B. M. (1994). Taxonomic note: a place for DNA-DNA reassociation and 16S rRNA sequence analysis in the present species definition in bacteriology. Int J Syst Bacteriol 44, 846-849.

Stolz, P., Hammes, W. P. \& Vogel, R. F. (1996). Maltosephosphorylase and hexokinase activity in lactobacilli from traditionally prepared sourdoughs. Adv Food Sci 18, 1-6.

Valcheva, R., Korakli, M., Onno, B., Prévost, H., Ivanova, I., Ehrmann, M. A., Dousset, X., Gänzle, M. G. \& Vogel, R. F. (2005). Lactobacillus hammesii sp. nov., isolated from French sourdough. Int J Syst Evol Microbiol 55, 763-767.

Vancanneyt, M., Neysens, P., De Wachter, M. \& 8 other authors (2005). Lactobacillus acidifarinae sp. nov. and Lactobacillus zymae sp. nov., from wheat sourdoughs. Int J Syst Evol Microbiol 55, 615-620.

Vogel, R. F., Knorr, R., Muller, M. R., Steudel, U., Ganzle, M. G. \& Ehrmann, M. A. (1999). Non-dairy lactic fermentations: the cereal world. Antonie van Leeuwenhoek 76, 403-411.

Weisburg, W. G., Barns, S. M., Pelletier, D. A. \& Lane, D. J. (1991). 16 S ribosomal DNA amplification for phylogenetic study. J Bacteriol 173, 697-703.

Yoon, J. H., Kang, S. S., Mheen, T. I. \& 7 other authors (2000). Lactobacillus kimchii sp. nov., a new species from kimchi. Int J Syst Evol Microbiol 50, 1789-1795. 